\title{
Home visit improves knowledge, self-care and adhesion in heart failure: Randomized Clinical Trial HELEN-I ${ }^{1}$
}

\author{
Cláudia Motta Mussi ${ }^{2}$ \\ Karen Ruschel ${ }^{3}$ \\ Emiliane Nogueira de Souza ${ }^{4}$ \\ Alexandra Nogueira Mello Lopes ${ }^{5}$ \\ Melina Maria Trojahn ${ }^{6}$ \\ Caroline Camargo Paraboni7 \\ Eneida Rejane Rabelo ${ }^{8}$
}

Objective: To verify the effect of an educative nursing intervention composed of home visits and phone calls on patients' knowledge about the disease, self-care and adhesion to the treatment. Methods: Randomized clinical trial with patients with recent hospitalization caused by decompensated heart failure. There were two groups: the intervention group, which has received four home visits and four phone calls to reinforce the guidelines during six months of follow up; and the control group, which has received conventional follow up with no visits or phone calls. Results: Two hundred patients were randomized (101 in the intervention group and 99 in the control group). After six months, a significant improvement was observed in self-care and knowledge about the disease in the intervention group $(P=0.001$ and $P<0.001)$, respectively; the adhesion to the treatment, measured and compared between the groups, was significantly higher in the intervention group $(P=0.001)$. Conclusion: the strategy of home visits to patients who were recently hospitalized with decompensated heart failure was effective in improving the outcomes assessed and its implementation deserves to be considered in Brazil aiming at avoiding unplanned hospitalizations. NCT-01213862

Descriptors: Patient Education (learning); Self Care; Adherence (compliance patient); Nursing; Home Visit.

\footnotetext{
${ }^{1}$ This research was supported by Fundação de Amparo à Pesquisa do Estado do Rio Grande do Sul, process \# FAPERGS: 09/0040-2 e do Fundo de Incentivo à Pesquisa do Hospital de Clínicas de Porto Alegre (FIPE), process \# 09-911, Brazil.

2 MSc, RN, Hospital de Clínicas de Porto Alegre, Brazil.

${ }^{3}$ RN, PhD.

${ }^{4} \mathrm{PhD}$, Adjunct Professor, Curso de Enfermagem, Universidade Federal de Ciências da Saúde, Porto Alegre, Brazil.

${ }^{5}$ RN, Hospital de Clínicas de Porto Alegre, Brazil.

${ }^{6}$ RN, Instituto de Cardiologia do Rio Grande do Sul, Brazil.

7 Undergraduate student in Nursing, Escola de Enfermagem, Universidade Federal do Rio Grande do Sul, Brazil.

${ }^{8} \mathrm{PhD}$, Adjunct Professor, Escola de Enfermagem, Universidade Federal do Rio Grande do Sul, Brazil.
}

Corresponding Author:

Eneida Rejane Rabelo da Silva

Universidade Federal do Rio Grande do Sul. Escola de Enfermagem

Rua São Manoel, 963

Bairro Santa Cecília

CEP: 90620-110, Porto Alegre, RS, Brasil

E-mail: eneidarabelo@gmail.com; esilva@hcpa.ufrgs.br 


\title{
Visita domiciliar melhora conhecimento, autocuidado e adesão na insuficiência cardíaca: ensaio clínico randomizado HELEN-I
}

Objetivo: verificar o efeito de uma intervenção educativa de enfermagem combinada, caracterizada por visita domiciliar e contato telefônico, em pacientes com internação recente por insuficiência cardíaca descompensada, no conhecimento da doença, nas habilidades para o autocuidado e na adesão ao tratamento, comparado ao acompanhamento convencional de pacientes no período de seis meses. Métodos: nsaio línico randomizado com pacientes que tiveram internação recente por insuficiência cardíaca descompensada. O grupo-intervenção recebeu quatro visitas domiciliares e quatro contatos telefônicos para reforço das orientações, em seis meses de acompanhamento; o grupo-controle recebeu acompanhamento convencional sem visitas e sem contatos telefônicos. Resultados: duzentos pacientes foram randomizados (101: intervenção e 99: controle). Após seis meses, observou-se melhora significativa no conhecimento e autocuidado para o grupo-intervenção $(p=0,001$ e $p<0,001)$, respectivamente; a adesão ao tratamento, aferida no final entre os grupos, foi significativamente maior no grupo-intervenção $(p<0,001)$. Conclusão: a estratégia de visita domiciliar para pacientes que se internaram recentemente por insuficiência cardíaca descompensada foi efetiva na melhora dos desfechos avaliados, e sua implementação merece ser considerada no Brasil, visando-se evitar internações não planejadas. NCT-01213862

Descritores: Aprendizagem; Cooperação do Paciente; Autocuidado; Enfermagem; Visita Domiciliar.

\section{Visita domiciliar mejora conocimiento, auto cuidado, adhesión en la insuficiencia cardíaca: Ensayo Clínico Aleatorizado HELEN - I}

\begin{abstract}
Objetivo: Verificar el efecto de una intervención educativa de enfermería combinada de visita domiciliaria y contacto telefónico en pacientes con internación reciente por insuficiencia cardiaca descompensada, en el conocimiento de la enfermedad, las habilidades para el autocuidado y la adhesión al tratamiento comparado con el acompañamiento convencional de pacientes en el período de seis meses. Métodos: Ensayo Clínico Aleatorizado en pacientes que fueron ingresados recientemente por insuficiencia cardiaca descompensada. El grupo intervención recibió cuatro visitas domiciliarias y cuatro contactos telefónicos para reforzar las orientaciones en seis meses de acompañamiento; el grupo control recibió acompañamiento convencional sin visitas y sin contactos telefónicos. Resultados: Fueron aleatorizados doscientos pacientes (101: intervención y 99: control). Tras seis meses, se observó una mejoría significativa en el conocimiento y el autocuidado para el grupo intervención $(P=0,001$ y $\mathrm{P}<0,001)$, respectivamente; la adhesión al tratamiento, comparada al final entre los grupos, fue significativamente mayor en el grupo intervención $(P<0,001)$. Conclusión: La estrategia de visita domiciliaria para pacientes internados recientemente por insuficiencia cardiaca descompensada fue efectiva en la mejora de los desenlaces evaluados y su implementación merece ser considerada en Brasil con objeto de evitar internaciones no planificadas. NCT01213862
\end{abstract}

Descriptores: Aprendizage; Autocuidado; Cooperación del Paciente; Enfermagem; Visita Domiciliaria.

\section{Introduction}

In Brazil, heart failure (HF) is considered the main cause of hospitalizations in the Unified Health System (SUS) for people over 65 years of age. Approximately $50 \%$ of patients who are discharged from hospital are rehospitalized within six months, and $70 \%$ of these rehospitalizations are related to the worsening of $\mathrm{HF}$, mainly accompanied by congestion ${ }^{(1)}$.
Some factors that contribute to these high rehospitalization rates due to decompensation of the HF are related to patients' limited knowledge on the disease and treatment, inability to recognize signs of worsening, difficulties to get access to health services, advanced age and inappropriate social support or social isolation ${ }^{(2)}$.

In this concerning scenario, multidisciplinary 
monitoring strategies have been tested in the nonpharmacological treatment management of HF patients, with benefits for the achievement and maintenance of clinical stability(3-5). This non-pharmacological approach is based on a continuing education and skills development process with a view to self-care practice, including constant re-evaluations ${ }^{(6-7)}$.

Results of meta-analyses about the nonpharmacological approach professionals apply in $\mathrm{HF}$ management present beneficial results in terms of knowledge improvement about treatment, self-care and adherence, besides a better quality of life and cost reduction. The heterogeneous nature of interventions and the different contexts they are applied in, however, as well as the number of professionals involved, make it difficult to interpret the benefit these results entail, due to difficulties to identify the best strategy and the best scenario to put these interventions in practice ${ }^{(8-10)}$. Results of reductions in hospital admissions and mortality were suggested when the intervention was accompanied by home monitoring( ${ }^{(8)}$.

Thus, the variation in these interventions in terms of the start (in hospital or post-discharge), the intervention scenario (outpatient clinic, home or specialized clinic) and duration (a sole visit or various months of monitoring) need to be studied in different health contexts, culture and social aspects(5).

In this context, the home visit (HV) approach gains room, as the team challenges the social risks, geographical aspects, climate and clinical practice itself, in an actual clinical environment, and has not been tested in Brazil for HF patients. In that scenario, this Randomized Clinical Trial (RCT) was developed to test the hypothesis that the HV approach for patients who were hospitalized with decompensated heart failure (DHF) improves their knowledge on the disease, self-care skills and treatment adherence in patients monitored during six months (intervention), in comparison with conventional follow-up (control). In this RCT, self-care was based on the concept developed by American authors, who define it as positive conducts that make people make decisions and practice activities that help them to maintain clinical stability and cope with the disease ${ }^{(6)}$.

This study gains relevance when considering that the best approach to promote positive health outcomes is to guarantee that the multidisciplinary team's orientations and care are actually accomplished individually in each patient's family and social context ${ }^{(11)}$. The possibility of testing this treatment approach in Brazil for such as prevalent syndrome can permit investments in resources with a view to its future implementation in the SUS.

\section{Objectives}

To check the effect of an educative nursing intervention that combines HV and telephone contact in patients who had been recently hospitalized due to DHF, considering their knowledge about the disease, selfcare skills and treatment adherence, in comparison with conventional patient follow-up, over a six-month period.

\section{Methods}

\section{Study design}

Randomized Clinical Trial (RCT), called Home based intErvention LEd by Nurse in Brazil (HELEN-I), registered in Clinical Trials under number NCT-01213862, blinded for outcome evaluation.

\section{Participants}

Male and female patients were included, aged 18 years or older, diagnosed with HF with systolic dysfunction (ejection fraction of $45 \%$ or less), hospitalized due to decompensation of the disease. Patients with communication barriers, diagnosed with acute HF secondary to sepsis, myocarditis, stroke, living at more than $20 \mathrm{~km}$ from the institutions or without the possibility of telephone contact were excluded. Hospitalized patients were located at the clinical hospitalization and emergency units through an active search during the study team's daily visits to these units.

RCT conducted at two referral centers for HF patient treatment in a metropolitan region, state of Rio Grande do Sul, with approval from the Research Ethics Committees at both institutions: 09-111 and 4339-09.

\section{Intervention}

The intervention group (IG) received systematic follow-up by nurses specialized in $\mathrm{HF}$ patient care through $\mathrm{HV}$ on the $10^{\text {th }}, 30^{\text {th }}, 60^{\text {th }}$ and $120^{\text {th }}$ day after hospital discharge, according to an established protocol, over six months, totaling four HV, separated by four telephone contacts to reinforce the orientations. During each HV, the patients' history was collected and patients were subject to a physical examination, the latter oriented by the Clinical Congestion Score ${ }^{12)}$; the Knowledge Questionnaire on $\mathrm{HF}^{(13)}$ and the adherence questionnaire ${ }^{(14)}$ were applied and, to evaluate selfcare, the European Heart Failure Self Care Behaviour 
Scale (EHFScBS) ${ }^{(15)}$ was used. All instruments had been validated for use in Brazil. During the visit, patient and caregiver/relatives (when present) received orientations about the disease, regular medication use and its effects, non-pharmacological care actions, such as weight control, hydrosaline restriction, physical exercise, annual vaccination, as well as clarifications about patients and relatives' doubts. During this visit, the team also reinforced that patients and caregivers should heed oscillations like a weight gain by two $\mathrm{kg}$ or more in one week, worsening of dyspnea when making efforts and worsening of cough. These observations were aimed at teaching patients to put in practice self-care actions, like more enhanced fluid or salt restrictions or early contact with the health service. Telephone contacts took place at intervals of 15 to 30 days after the HV.

The control group (CG) maintained conventional follow-up at the institutions of origin, which could include outpatient consultations or not. At the end of six months of monitoring, patients in both groups were assessed at the referral hospitals.

\section{Outcomes}

The primary outcomes were the change in knowledge about the disease, self-care and treatment adherence.

To check knowledge about $\mathrm{HF}$, a 14-question questionnaire was applied ${ }^{(13)}$. The knowledge percentage was determined by adding up the number of correct answers, with a maximum score of 14 correct answers, corresponding to a knowledge percentage of $100 \%$ about $100 \%$. Knowledge was considered adequate when the patient reached $70 \%$ of correct answers. To measure self-care skills, the EHFScBS scale was used, which consists of 12 questions. EHFScBS scores vary between 12 (better self-care) and 60 points (worse self-care)(15). To check adherence, a ten-question questionnaire was used. The score ranges between 0 and 26 points; the higher the score, the better the patient's adherence. Adherence was considered appropriate when the patient reached 18 points, corresponding to $70 \%{ }^{(14)}$.

\section{Sample size}

For knowledge about the disease(13), self-care skills $^{(7)}$ and adherence ${ }^{(14)}$, and in the attempt to comply with the minimal size needed to cover all outcomes, a sample of 89 patients was sued in each group, totaling
178 , considering $20 \%$ of losses for a total alpha of 0.05 and $80 \%$ power. At the end of the study, 200 patients were included.

\section{Randomization}

Simple sequence randomization was used, generated electronically on the website www. randomization.com. One available professional who was not a member of the research group was responsible for the patient allocation list.

\section{Blinding}

The intervention nurses were blinded to the patient allocation group until all instruments had been completed in the baseline period. A nurse who was blinded to the group the patient had been allocated to was responsible the final evaluations of all patients and outcomes.

\section{Statistical analysis}

Continuous variables were expressed as means and standard deviations for variables with normal distribution, while medians and interquartile intervals were used for asymmetric variables. Student's independent t-test, Chi-square and Mann-Whitney's U-test were used to compare baseline characteristics between the groups. Student's independent t-test was used to compare the outcomes knowledge about the disease, self-care and treatment adherence. The generalized estimating equation (GEE) test with Bonferroni's adjustment was used to compare the knowledge, self-care and adherence scores. Significance was set at $P<0.05$. Statistical software SPPS v.18 was used for these analyses.

\section{Results}

Between 08/10/2009 and 01/11/2012, 1452 potentially eligible patients were admitted due to the DHF at the two referral institutions under analysis. In this group, 916 were excluded because they presented at least one exclusion criterion, 10 gave up participating and 326 were excluded for other reasons. Two hundred patients were randomized for the study, 101 for the IG and 99 for the CG. After the randomization, four patients from IG were discharged due to death. During followup, 12 deaths were observed in the IG and 18 in the CG. At the end of the six-month follow-up, 151 patients completed the study and were analyzed (Figure 1). 


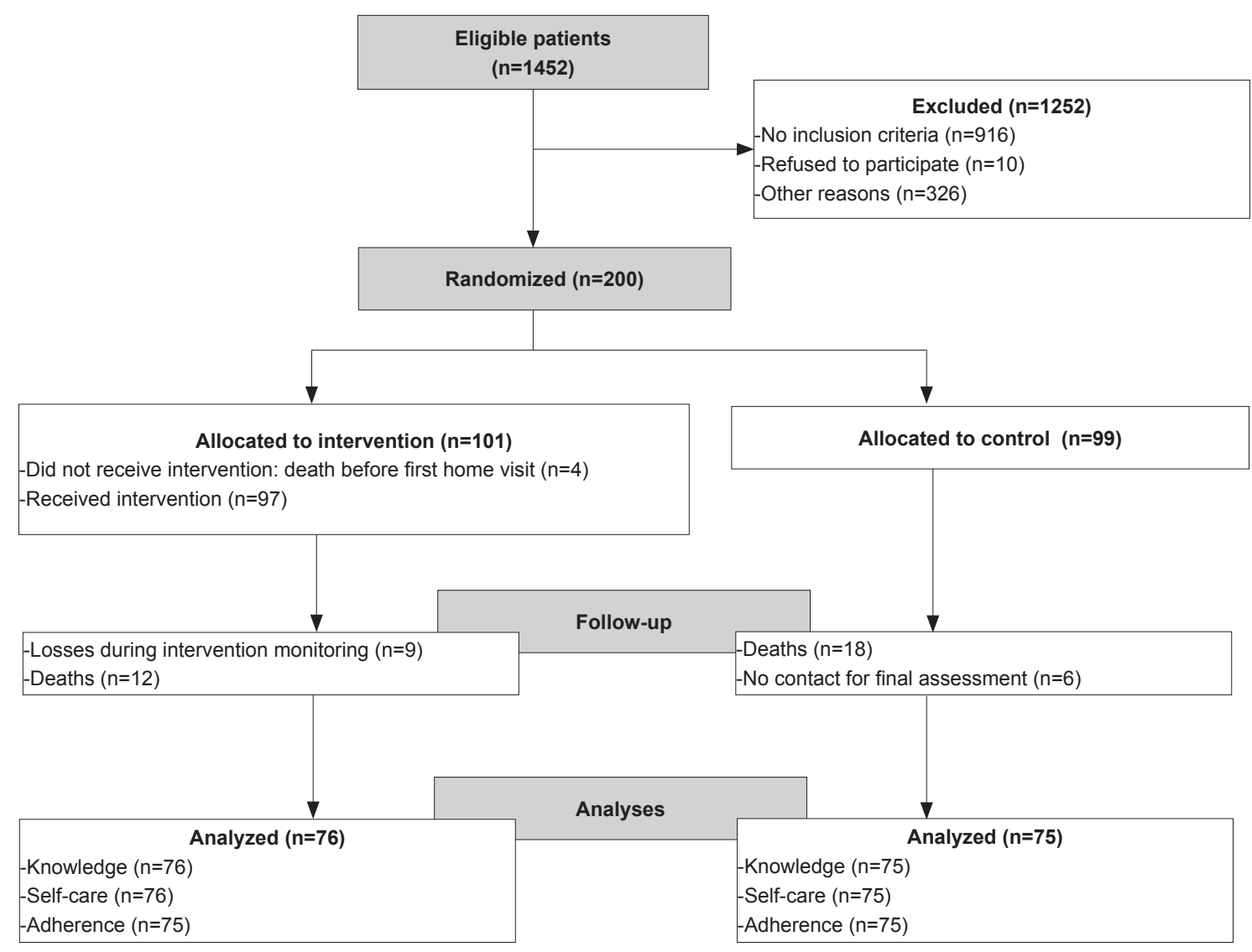

Figure 1 - Consort Diagram. Porto Alegre, RS, Brazil, 2012

\section{Sociodemographic and clinical characteristics}

Table 1 illustrates the groups' baseline characteristics. The mean age in IG was $62.49 \pm 13.65$, against $63.37 \pm 12.05$ in CG. In both groups, patients were predominantly male. The mean ejection fraction was $29.29 \pm 8.04$ for IG and $30.31 \pm 9.55$ for CG. The most prevalent cause was ischemic $(35.6 \% ; 31.3 \%)$ in IG and CG, respectively. Diabetes and systemic arterial hypertension were the most prevalent comorbidities. Groups showed no differences in terms of baseline characteristics.

Table 1 - Sociodemographic and clinical characteristics of heart failure patients. Porto Alegre, RS, Brazil, 2012

\begin{tabular}{lccc}
\hline & $\begin{array}{c}\text { Intervention } \\
(\mathbf{n = 1 0 1 )}\end{array}$ & $\begin{array}{c}\text { Control } \\
(\mathbf{n}=99)\end{array}$ & $\mathbf{P}^{*}$ \\
\hline $\begin{array}{l}\text { Sociodemographic data } \\
\mathrm{Age}^{\dagger}\end{array}$ & $\begin{array}{c}6.49 \pm 13.65 \\
\text { Male gender (\%) }\end{array}$ & $\begin{array}{c}63.37 \pm 12.05 \\
\text { Education }\end{array}$ & 0.63 \\
$\begin{array}{l}\text { Did not attend (\%) } \\
\begin{array}{l}\text { Unfinished primary } \\
\text { education (\%) }\end{array}\end{array}$ & $4(4.0)$ & $9(9.1)$ & 0.91 \\
$\begin{array}{l}\text { Unfinished secondary } \\
\text { education (\%) }\end{array}$ & $94(63.4)$ & $70(70.7)$ & \\
$\begin{array}{l}\text { Finished secondary } \\
\text { education (\%) }\end{array}$ & $24(23.8)$ & $11(11.1)$ & \\
Lives alone (\%) & $12(11.9)$ & $10(10.3)$ & 0.72
\end{tabular}

\begin{tabular}{|c|c|c|c|}
\hline & $\begin{array}{c}\text { Intervention } \\
(n=101)\end{array}$ & $\begin{array}{c}\text { Control } \\
(\mathrm{n}=99)\end{array}$ & $\mathbf{P}^{*}$ \\
\hline \multicolumn{4}{|l|}{ Clinical data } \\
\hline Ejection fraction ${ }^{\dagger}$ & $29.29 \pm 8.04$ & $30.31 \pm 9.55$ & 0.42 \\
\hline \multicolumn{4}{|l|}{ Congestion score ${ }^{\dagger}$} \\
\hline Baseline & $5.52 \pm 3.35$ & $5.31 \pm 3.27$ & 0.65 \\
\hline Final & $3.93 \pm 3.53$ & $4.41 \pm 3.84$ & 0.36 \\
\hline Functional class (\%) & & & 0.63 \\
\hline 1 & $7(7.1)$ & $6(6.1)$ & \\
\hline$\|$ & $38(38.4)$ & $44(44.9)$ & \\
\hline III & $41(41.4)$ & $40(40.8)$ & \\
\hline IV & $13(13.1)$ & $8(8.2)$ & \\
\hline Etiology (\%) & & & 0.08 \\
\hline Ischemic & $36(35.6)$ & $31(31.3)$ & \\
\hline Hypertensive & $32(31.7)$ & $29(29.3)$ & \\
\hline Valve & $2(2.0)$ & $12(12.1)$ & \\
\hline Idiopathic & $22(21.8)$ & $17(17.2)$ & \\
\hline Others & $9(8.9)$ & $10(10.1)$ & \\
\hline \multicolumn{4}{|l|}{ Comorbidities (\%) } \\
\hline Diabetes Mellitus & $37(36.6)$ & $34(34.3)$ & 0.73 \\
\hline $\begin{array}{l}\text { Systemic Arterial } \\
\text { Hypertension }\end{array}$ & $63(64.3)$ & $75(75.8)$ & 0.08 \\
\hline $\begin{array}{l}\text { Chronic Obstructive } \\
\text { Pulmonary Disease }\end{array}$ & $13(13.1)$ & $17(17.5)$ & 0.39 \\
\hline Depression & $22(22.2)$ & $22(22.4)$ & 0.97 \\
\hline
\end{tabular}

*P comparison between groups using Student's t-test, Pearson's Chisquare or Mann-Whitney's U-test

${ }^{+}$Continuous variables expressed as means \pm standard deviation; categorical variables as $\mathrm{n}(\%)$. 


\section{Knowledge on HF, self-care and adherence}

Figure 2 displays the variation in primary outcome scores across the six-month follow-up. At the end of the study period, improvements were observed in HF knowledge, self-care skills and treatment adherence. The mean percentage of correct answers on the knowledge questionnaire was $46.32 \% \pm 16.21$ for IG and $45.19 \% \pm 16.43$ for CG and, for the selfcare questionnaire, $34.45 \pm 7.71$ and $34.05 \pm 7.66$, respectively. Six months later, both groups significantly improved their scores in comparison with baseline, for knowledge (IG 71.15\% $\pm 13.82 ; \quad \mathrm{P}<0.001$; CG $54.95 \pm 15.04 ; \mathrm{P}<0.001$ ) as well as for self-care (IG $22.36 \pm 6.46 ; P<0.001 ; C G 30.91 \pm 7.30 ; P=0.002$ ), with a greater increase for IG on both questionnaires (Figure 2 ). In IG, the knowledge score increased 16 points in comparison with CG, representing a $24.8 \%$ knowledge increase in IG versus $9.76 \%$ in CG. When assessed visit by visit, knowledge increased significantly between baseline and HV1 $(P<0.001)$ and between HV3 and HV4 $(P=0.004)$. As regards self-care, the score improvement only differed between HV1 and HV2 $(P<0.001)$. In selfcare, the mean score difference between the groups was also significant for IG, $12.09(P<0.001)$ versus 3.13 $(P=0.002)$ for $C G$. In the assessment of the adherence questionnaire, at the end of the follow-up, an increase was observed in the number of correct answers when compared to HV1 (57.44\% \pm 11.96 - 73.52\% \pm 10.26 ; $\mathrm{P}<0.001)$ for IG, showing a higher score than in CG $(P<0.001)$ at the end of the study. When considering visit by visit, this increase was only significant between HV1 and HV2 $(P<0.001)$.
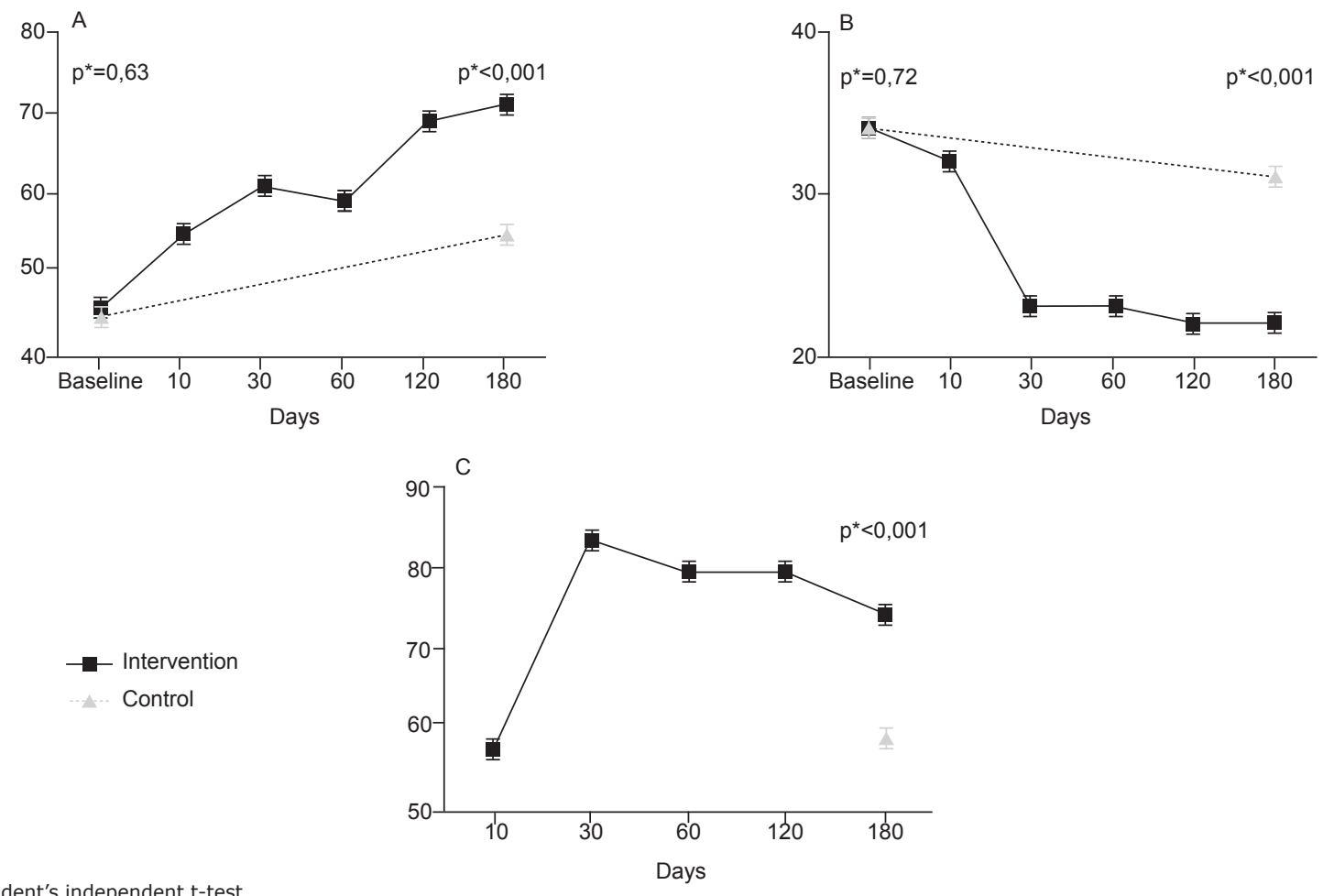

*P: Student's independent t-test.

Figure 2 - Outcome score variation throughout six-month follow-up. (A) Baseline knowledge $(P=0.63 ; 95 \% C I-3.34$ - 5.69) and final $(P=0.001 ; 95 \% C I 11.62-20.77)$; $(B)$ Baseline self-care $(P=0.72 ; 95 \% C I-1.82-2.62)$ and final $(P<0.001 ; 95 \% C I-10.82--6.30)$; $(C)$ Final adherence $P=0.001$ (95\% -19.69- -10.04). The generalized estimating equations (GEE) test with Bonferroni's adjustment was applied to compare both groups (intervention with home visits and control without visits). Porto Alegre, RS, Brazil, 2012

\section{Discussion}

HELEN-I is the first RCT developed in Brazil that showed improved knowledge about the disease, self-care skills and treatment adherences in patients hospitalized with DHF who were monitored for six months after discharge through $\mathrm{HV}$, in comparison with patients who did not receive this intervention. www.eerp.usp.br/rlae
The intervention resulted in knowledge improvements in both groups when comparing baseline and final assessments. In IG, however, the knowledge score increased by 16 points in comparison with CG, representing a $24.8 \&$ increase in knowledge, versus 
9.76\% in CG. In between the visits, knowledge increased significantly between baseline evaluation and HV1 $(\mathrm{P}<0.001)$ and between HV3 and HV4 $(P=0.004)$. Regarding self-care, the score improvement only differed between HV1 and HV2 $(P<0.001)$. It is highlighted that the mean score difference between the groups was also significant for IG, corresponding to $12.09(P<0.001)$ versus $3.13(P=0.002)$ for $C G$. Similar results were demonstrated in a recent publication on a Latin American RCT, involving HF patients who received a home intervention, educative meetings, reinforcement through tele-monitoring and an orientation folder, with a nine-month follow-up. In that study, the outcome assessed was self-care behavior. For the group that received the proposed compound intervention, a $20 \%$ increase was verified on the self-care behavior scale, confirming the beneficial effect of this approach(16). The improvements in knowledge about the disease and selfcare were also evaluated in an RCT in which, in both groups, patients received education about the disease and treatment during hospitalization due to DHF. After discharge, only one of the groups was randomized to receive tele-monitoring for three months, aimed at reinforcing orientations. The authors demonstrated significant improvements in knowledge about the disease and self-care for both groups at the end of three months, independently of telephone $\operatorname{contact}^{(17)}$. These results indicate that education about $\mathrm{HF}$ and the aspects involved in its complex treatment is a key-point to involve patients in their self-care. During hospitalization due to DHF - which entails clinical manifestations that lead to instability, with clear physical limitations, in most cases deriving from congestive conditions - the hospital context makes patients more sensitive to awarenessraising on the importance of self-care. In a review, the authors indicate that this is the most important moment to start the education process about HF and self-care ${ }^{(18)}$. In addition, when these orientations are put in practice at home, nurses are able to make adjustments and combinations, together with patients, based on their real world and feasible. The six-month follow-up in this study and the verification of outcomes during the monitoring period revealed that patients need a learning period, after which they understand the orientations and value the incorporation of non-pharmacological measures into the complex pharmacological treatment of HF.

The adherence outcome was compared between the two groups only for the final study visit. At the end of the monitoring period, a significant difference was observed between the groups, in which IG reached the recommended percentage for appropriate adherence, exceeding $70 \%, \mathrm{P}<0.001$, while CG, without intervention, scored approximately $60 \%$. In IG, adherence was verified as from HV1, and a $28 \%$ increase was found between that visit and the end of the study, with an effect size of 1.45 times in comparison with CG at the end. In a similar study, involving $283 \mathrm{HF}$ patients, who received an intensive intervention that started upon discharge, including information about the disease, pharmacological and non-pharmacological treatment and an orientation manual elaborated especially for the study, adherence was verified as a secondary outcome. Using HV and telephone calls by the nurse every 15 days for one year, this group was compared with patients who received usual care by a cardiologist. The study results indicated that HV promoted $86.1 \%$ of adherence in IG and $75.5 \%$ in $\mathrm{CG}^{(19)}$. In an RCT developed in Brazil that investigated the effects of a management program for stable HF patients through repeated educative sessions and long-term follow-up, the treatment adherence outcome was also verified. Average adherence scores were higher for patients who received the intervention when compared to the group without intervention. The adherence score sequence in this group across a two and a half-year follow-up period was maintained until the end, while adherence scores gradually dropped among controls. Those authors suggested that adherence monitored over a long time can serve as an additional strategy to prevent the reduction of possible beneficial effects achieved in patients ${ }^{(14)}$.

Other studies with an HV approach have been conducted with HF patients, but focused on effects on clinical outcomes like rehospitalizations, mortality and costs. Unfortunately, this strategy has not been capable of showing these effects in isolation(20-21).

The present study results indicate that this strategy tested is original in the Brazilian context for patients who were recently hospitalized due to DHF. The effect of improvements in knowledge, self-care skills and adherence can benefit patients and can also influence important clinical results. Therefore, tests should be continued in different contexts.

\section{Conclusion}

The HV approach with telephone orientations for reinforcement during a six-month follow-up for patients with HF who had recently been hospitalized due to decompensation resulted in better knowledge on the disease, greater self-care skills and greater adherence. 
These results indicate that this strategy should be implemented in Brazil with a view to avoiding unplanned hospitalizations.

\section{References}

1. Gaui EM, Klein CH, Oliveira GM. Mortalidade por Insuficiência Cardíaca: análise ampliada e tendência temporal em três estados do Brasil. Arq Bras Cardiol 2010;94(1):55-61.

2. van der Wal $\mathbf{M H}$, Jaarsma T, Van Veldhuisen DJ. Noncompliance in patients with heart failure: how can we manage it? Eur Heart J. 2005;7(1):5-17.

3. Klersy C, Silvestri AD, Gabutti G, Regoli F, Auricchio

A. A Meta-analysis of remote monitoring of heart failure patients. JACC. 2009;27:1683-94.

4. Roccaforte R, Demers C, Baldassarre F, Teo KK, Yusuf

$S$. Effectiveness of comprehensive disease management programmes in improving clinical outcomes in heart failure patients. A meta-analysis. Eur J Heart Fail. 2005;27:1133-44.

5. Gonseth J, Guallar-Castilló P, Banegas JR, RodríguezArtalejo. The effectiveness of disease management programmes in reducing hospital re-admission in older patients with heart failure: a systematic review and meta-analysis of published reports. Eur Heart $\mathrm{J}$. 2004;25:1570-95.

6. Riegel B, Moser DK, Anker SD, American Heart Association Council on Cardiovascular Nursing, Council on Cardiovascular Nursing, Council on Clinical Cardiology, et al. State of the science: promoting selfcare in persons with heart failure: a scientific statement from the American Heart Association. Circulation. 2009;120:1141-63.

7. Jaarsma T, Strömberg A, Mårtensson J, Dracup

K. Development and testing of the European Heart Failure Self-Care Behaviour Scale. Eur J Heart Fail. 2003;5(3):363-70.

8. Holland R, Battersby J, Harvey I, Lenaghan E, Smith J, Hay L. Systematic review of multidisciplinary interventions in heart failure. Heart. 2005;91(7):899906.

9. Holland R, Desborough J, Goodyer L, Hall S, Wright $D$, Loke YK. Does pharmacist-led medication review help to reduce hospital admissions and deaths in older people? A systematic review and meta-analysis. Brit J Clin Pharmacol. 2007;65(3):303-16.

10. Sally CI, Robyn AC, Finlay AM, Stewart S, Cleland JGF. Which components of heart failure programmes are effective? A systematic review and meta-analysis of the outcomes of structured telephone support or telemonitoring as the primary component of chronic heart failure management in 8323 patients: Abridged Cochrane Review. Eur J Heart Fail. 2011;13:1028-40.

11. Artinian NT, Magnan M, Sloan M, Lange PM. Selfcare behaviours among patients with heart failure. Heart Lung. 2002;31(3):161-72.

12. Rohde LE, Silva LB, Goldraich L, Grazziotin TC, Palombini DV, Polanczyk CA, et al. Reliability and prognostic value of traditional signs and symptoms in outpatients with congestive heart failure. Can J Cardiol. 2004;20(7):697-702.

13. Rabelo ER, Mantovani VM, Aliti GB, Domingues FB. Cross-cultural adaptation and validation of a disease knowledge and self-care questionnaire for a Brazilian sample of heart failure patients. Rev. Latino-Am. Enfermagem. 2011;19(2):277-84.

14. Bocchi EA, Cruz F, Guimarães G, Moreira LFP, Issa VS, Ferreira SMA, et al. A Long Term Prospective Randomized Controlled Study Using Repetitive Education at SixMonth Intervals and Monitoring for Adherence in Heart Failure Outpatients: The REMADHE Study. Circulation. 2008;3:1-23.

15. Feijó MK, Ávila CW, Souza EN, Jaarsma T, Rabelo ER. Adaptação transcultural e validação da European Heart Failure Self-care Behavior Scale para o Português do Brasil. Rev. Latino-Am. Enfermagem; 2012 (prelo).

16. Rodriguez-Gasquez MA, Arredonho-Holguin $E$, Herrera-Corte R. Effectiveness of an educational program in nursing in the self-care of patients with heart failure: randomized controlled trial. Rev. Latino-Am. Enfermagem. 2012;20(2):296-306.

17. Domingues FB, Clausell N, Aliti GB, Dominguez DR, Rabelo ER. Education and telephone monitoring by nurses of patients with heart failure: randomized clinical trial. Arq Bras Cardiol. 2011;96(3):233-9.

18. Aliti GB, Rabelo ER, Domingues FB, Clausell N. Educational settings in the management of patients with heart failure. Rev. Latino-Am. Enfermagem. 2007; 15(2):344-9.

19. Brotons C, Falces C, Alegre J, Ballarín E, Casanovas J, Catà T, et al. Randomized Clinical Trial of the Effectiveness of a Home-Based Intervention in Patients With Heart Failure: The IC-DOM Study. Rev Esp Cardiol. 2009;62(04):400-8.

20. Leventhal ME, Denhaerynck K, Brunner-La Rocca HP, Burnand B, Conca-Zeller A, Bernasconi AT, et al. Swiss Interdisciplinary Management Programme for Heart Failure (SWIM-HF): a randomised controlled trial study of an outpatient inter-professional management 
programme for heart failure patients in Switzerland.

Swiss Med Wkly. 2011;141:w13171.

21. Jaarsma $T$, van der Wal MH, Lesman-Leegte I, Luttik $M L$, Hogenhuis J, Veeger NJ, et al. Effect of moderate or intensive disease management program on outcome in patients with heart failure: Coordinating Study Evaluating Outcomes of Advising and Counseling in Heart Failure (COACH). Arch Intern Med. 2008;168:316-24. 